Sam Heijnen*

\title{
Athens and the Anchoring of Roman Rule in the First Century BCE (67-17)
}

\author{
https://doi.org/10.1515/jah-2017-0023
}

\begin{abstract}
The early Augustan Age witnessed an increase in building activities and overall interest in mainland Greece which has primarily been understood from the perspective of Roman appropriation of Greek culture, or from that of local Greek independence and "re-Hellenization." Taking late Republican Athens as an extensive case study, this article shows that, when moving beyond either a topdown or bottom-up vision, developments in the late Republican and early Augustan Age can be properly contextualized as being part of a continuous strategy of Roman leaders and the Athenian elite to negotiate power and influence within a shared field of references.
\end{abstract}

Keywords: Athens, Anchoring, Roman Civil Wars, Euergetism, Augustus

Athens' (re)incorporation in the Roman Empire after the Battle of Actium in 31 was preceded by a turbulent period of violent conflicts (both internal and external). Following the disastrous sack of Athens by the Roman commander Lucius Sulla in 86, Athens continued to end up on the losing side of Rome's wars. The city supported Pompey in his war against Julius Caesar, Brutus and Cassius in theirs against Octavian and Antony, and lastly Antony in his attempt for sole rule against Octavian. Whether the Athenians collectively and deliberately chose a side in these conflicts is debatable. Since at least two of the Roman generals mentioned above appeared with armies at the city's gates, one can wonder to what extent the Athenians really had a choice. Furthermore, internal factionalism, opportunism, and sheer misfortune all seem to have influenced the course of events of the mid- and late first century BCE. Nevertheless, one can imagine that in 31 the mood in the Athenian Boulè must have been uneasy when it became

\footnotetext{
Note: All dates are BC/BCE unless indicated otherwise. All translations of the accounts of the ancient authors are from the Loeb Classical Library. I have added more current expressions when deemed appropriate. The translations of the inscriptions are my own. Abbreviations are in accordance with the Oxford Classical Dictionary (fourth edition).
}

*Corresponding author: Sam Heijnen, Radboud University, Department of History, Erasmusplein 1, 6500 HD, PO Box 9103, Nijmegen (NL), E-Mail: s.heijnen@let.ru.nl 
apparent that the city had once again sided with the losing party. The victor in this case was Octavian, who would become the first emperor of the Roman Empire.

The Romans had always been wary of influences from the Greek East. Luxuria and decadence, notions long attributed to the Greek East, were considered to be a danger for Roman society. In the last decades of the civil wars, Octavian ingeniously used this sentiment in his war against Egypt. ${ }^{1}$ By degenerating or "othering" these notions and those subjected to it (Mark Antony and Cleopatra) Octavian was able to substantiate his leadership for conservative Romans. ${ }^{2}$ However, the Romans simultaneously valued their true Greek neighbors in (mainland) "Old Greece," especially at Athens, for their cultural values and heritage. ${ }^{3}$ The Classical Greek civil and military values in particular were seen as exemplary moral standards (mores), and were therefore worth promoting. Roman admiration for Greece's past was strengthened by the fact that the legendary victory of the Greeks over the Persians was particularly useful to fuel the symbolism and rhetoric of Rome's war with Parthia. ${ }^{4}$

Augustus' building activities and his participation in religious ceremonies in cities such as Athens and Sparta are, then, believed to have been part of a larger sociocultural policy of promoting the mythical and Classical legacy of Greek cities under Rome, to the effect that their heritage may in turn aid in the self-promotion and legitimization of Augustus' rule. ${ }^{5}$ This Augustan model would then supposedly have resulted in a renewed emphasis placed on Greek culture, in effect "a Romanisation of Greece achieved (...) through a process of 're-hellenisation' for which the impulse came from the west." ${ }^{6}$ This view has received a fair amount of

1 Swain and Davies (2010), 319. See also Orlin (2008).

2 Lange (2009).

3 E.g. Cic. Flac. 62, Q Fr. 1.1.28; Plin. Ep. 8.24. Also Shear Jr. (1981), 356-358. For a discussion on these (ambivalent) Roman views of Greece, see Isaac (2004), 316-323, 381-406. Also on Roman adaptation and appropriation of Greek art and culture, see Hölscher (2004), Wallace-Hadrill (2008), and especially Gruen (2011).

4 Spawforth (1994).

5 Most notably Spawforth (2012), building upon Wallace-Hadrill (2008). This theory, however, should not solely be attributed to Spawforth, as Walker, for example, has already argued with regard to the Athenian Agora that "the reason for creating, as it were, a sacred museum of religious art and architecture in Athens may be sought in the role played by the classical polis in Augustan moral propaganda, a role very clearly seen in the art and architectural decoration of Augustan Rome (...)," see Walker (1997), 72. Cf. Thompson (1987), 7-9; Stefanidou-Tiveriou (2008), 28; Evans (2011), 90-93. The term "museum," however, suggests passive instead of active engagement with the Agora's buildings and surroundings. The Agora was, however, still actively used in the early imperial period, see Dickenson (2011).

6 Spawforth (2012), 28. 
criticism. The extent to which "top-down" Augustan propaganda was the driving force behind the Greeks' (renewed) interest in their culture and past, and in turn the driving force behind the restoration of Classical temples and the revival of ancient religious practices, is questionable. ${ }^{7}$ One important question that is often overlooked is to what extent the emphasis on the mythical and Classical past in mainland Greece around the change of the millennium is truly exceptional. ${ }^{8}$ Therefore, this paper intends to shift the debate's focus from Augustan Greece to earlier encounters between Greeks and Romans in the first century BCE, taking Athens as an indicative case study. ${ }^{9}$ Through combining literary, epigraphic, numismatic, and archaeological evidence, it aims to gain a thorough understanding of the political climate of the first century BCE. It will demonstrate that, in the case of Athens, the iconic "turn to the past" was by no means an Augustan invention; rather, it was a continuous way for the Athenians and Roman leaders of the first century BCE to find a shared field of references to present Roman rule in a traditional framework. Greek culture and the Greek past provided a useful

7 Vlassopoulos (2013), 184; Stewart 2012. Cf. "We should (...) imagine that the transformation of public space in Greece was the result of a dialectic process of interaction between the imperial power and local communities and we should certainly not underestimate the degree of influence of the latter" (my emphasis), see Dickenson (2017), 209. See also the discussion on the assimilation of Livia with Hestia in Athens, which supposedly mirrored contemporary assimilations of imperial women with Vesta in Rome. However, it turns out that Vesta played no significant part in their representation. On the earlier assumption that "sous l'influence de la Vesta romaine, la vénération de la Hestia athénienne fut introduite sur l'Acropole," see Kantiréa (2007), 126-129, also Spawforth (2012), 202-203, both following Kajava (2001). This assumption turned out to be incorrect, for which see Foubert (2015).

8 Exceptions include the contributions in Schmitz and Wiater (2011), and in Dijkstra, et al. (2017). Morales (2017), esp. 151-153, which appeared after submission of this article, has argued along similar lines with regard to the importance of the history of euergetism in understanding Augustan interventions in Athens.

9 Relatively little attention is devoted to the period between Sulla's sack of the city (86) and the start of the Principate (27), especially in comparison to that to Augustan Athens. Still, some complementary analyses include Geagan (1967); Hoff (1989a); Habicht (1995), 315-365, (1997); Rödel-Braune (2010); Mango (2010). Telin (2016) discusses Roman and Italian visitors and residents in Athens yet excludes state-officials such as Sulla, Pompey, Caesar, Antony, and Agrippa. On the honors devoted to Romans and Italians in Greece in the first two centuries BCE, see still Payne (1984), also Parigri (2013). On the developments of the Athenian Agora in this period, see Dickenson (2017), 142-188. Sulla's reign over Athens and that of Hellenistic kings will sporadically be discussed to address historical (dis)continuity, but will not be discussed an sich. On Hellenistic Athens, see Habicht (1995); Mikalson (1998); Rathmann (2010). On the politics of the second and early first century BCE, see Waterfield (2014); Rosillo-López (2015). On Sulla's reign over Athens, see Geagan (1967); Habicht (1995), 297-314; Rathman (2010), 82-84; Mango (2010), 119-124; Kuin (2017). 
repertoire in this regard. Understanding the process behind this can perhaps best be understood by the notions of finding "common ground" and "anchoring" (terms derived from communication theory and social psychology).

The search for Rome to find common ground with provincial cities, through which power was negotiated and exercised, has already been extensively discussed by Ando (as consensus) and others in the last two decades. ${ }^{10}$ Modern studies in the fields of Roman history and archaeology have indeed shown that Roman rule was embedded in pre-existing structures (in the case of the imperial cult even quite literally), ${ }^{11}$ but such studies have not always considered the theoretical assumptions behind such forms of interaction. For it is only possible to find common ground when communication works, and in order for communication to work, there is need for shared terminology. ${ }^{12}$ Pre-existing worldviews and their symbolic manifestations could help in this regard. One of the clearest examples of how this process works can perhaps be found in Egypt, where several statues of Roman emperors survive in the guise of pharaohs, thereby "translating” Roman rule in Egyptian terms. ${ }^{13}$ This strategy was neither new, nor necessarily initiated from the imperial center. ${ }^{14}$ In fact, in many cases (including the case of the emperor in Egypt) it is unknown to us who "produced" the image of the emperor. ${ }^{15}$ The important thing is that there was an apparent need to convey such messages with certain cognitive footholds (i.e. "anchors") in mind. This process can be defined by the notion of anchoring-a process by which new situations are presented in line with what people expect and understand. ${ }^{16}$ Anchoring was not

10 Ando (2001); Noreña (2011); Hekster (2015), 25-30, with references. On common ground theory, see Clark (1996).

11 Kantiréa (2007) and Camia (2016) for Roman Greece. On Roman Athens specifically, see Shear Jr. (1981). Still Price (1984) for Asia Minor.

12 Clark (1996). Schramm's (1954) communication model is also useful in this regard. The model implies that in order for messages to be understood, the sender (encoder) needs to formulate these into a code that is known to the receiver (decoder). Craig (1999) on the concept of "shared field of experience." See also Trimble (2017), 107, 110-113, n. 12. One could (and perhaps even should) go one step further and argue that shared terminology is only possible if cultural notions are shared, which in turn is only possible in an interconnected environment, for which see Pitts and Versluys (2015).

13 E.g. Cairo, Cairo Museum, inv. no. 701 (Augustus/Tiberius), see Johannes (1975), no. 13, taf. 14-15; Kiss (1984), 42-43, 139, figs. 67-68; Boschung (1993), no. 268; Brophy (2013), 23, no. 1.

14 On the use of the Pharaonic legacy in the (self-)representation of the Ptolemaic kings and queens, see Kiss (1984), 21-26; Stanwick (2002), 33-42, 88.

15 Questions on agency have mainly assumed either a top-down or bottom-up model, for more on this issue see Hekster, et al. (2014), 8 with references.

16 On the concept of "anchoring," see Sluiter (2017); Hekster (2017). For the original use of the term in psychology, see Tversky and Kahneman (1974). 
only crucial for Rome to legitimize its rule, but it was likewise important for its subjects to understand and accommodate (political) change.

Pompey the Great's visits to Athens (in 67 and 62) provide a good starting point. Pompey was granted imperium by the Roman Senate to deal with pirates in the Eastern Mediterranean (the Lex Gabinia). "But though his immediate business was urgent and he sailed past other cities in his haste, still, he could not pass Athens by," says Plutarch (Pomp. 27). Unfortunately, we do not have significant material evidence to accompany Plutarch's account. Two preserved statue-bases from the Acropolis mention Pompey's father and grandfather ( $\mathrm{Cn}$. Pompeius Strabo and Sex. Pompeius), and might have been erected on occasion of Pompey's visit in $62 .{ }^{17}$ Plutarch also mentions that the Athenians bestowed divine honors upon Pompey by putting up inscriptions on one of Athens' city gates (Pomp. 27), probably either the Dipylon or Piraeus Gate, yet these have thus far not been found. It has also been suggested that Athenian bronze coins from the Agora (roughly dated between 70 and 40), which bear a dolphin and trident on the obverse (symbols of Poseidon), and a plemochoe (a vessel that was connected to rituals in the Eleusinian Mysteries) ${ }^{18}$ with ears of wheat on the reverse, might allude to Pompey's initiation into the Eleusinian Mysteries in September 62. ${ }^{19}$ However, conclusive evidence for Pompey's initiation is lacking. In any case, the attributes of Poseidon must have held some significance, as this was, as Kroll has shown, "the only pre-imperial Athenian coin type that refers to Poseidon."20 If not a reference to Pompey's initiation in the Mysteries, they were likely to have been a commemoration of Pompey's sweep through the eastern Mediterranean to clear it from pirates (67-66). As peace was restored on sea by Pompey, symbols of Poseidon would be an appropriate reference to current events. ${ }^{21}$

What we do know with more certainty is that Pompey granted Athens fifty talents to rebuild parts of the city that were destroyed by Sulla two decades earlier (Plut. Pomp. 42; Cic. Att. 6.1.25). A line from the Athenian restoration decree indicates that part of the funds were probably used to restore Athens' harbor, as it records repairs to a waterfront bazaar of Magnus (i.e. Pompey the Great) at

17 IG II 2 4100, 4101. Cf. Hoff (2005), 332.

18 For a discussion on the vessel in connection with the Eleusinian Mysteries, see Mitsopoulou (2011).

19 Kroll (1993), 99-100, no. 129; Hoff (2005), 332.

20 Kroll (1993), 99.

21 For more on the connection between Pompey and Poseidon/Neptune, see La Rocca (19871988). 
Piraeus. ${ }^{22}$ According to Plutarch, the reason for Pompey to financially support Athens and other cities was "to set foot in Italy with a reputation more brilliant than that of any other man" (Pomp. 42). Plutarch refers to the practice known as

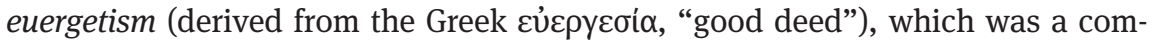
mon practice amongst the Hellenistic kings of the Greek East, especially the Attalids, who repeatedly adorned cities such as Athens with monuments to improve their cultural ties with the traditional centers of Greek culture.

Interestingly, some twelve years later, Athens received the same amount of funds (fifty talents) from Pompey's triumviral rival, Julius Caesar. ${ }^{23}$ In a letter to his friend Atticus, Cicero reports the following: “And look here, has Herodes [of Marathon] really squeezed 50 Attic talents out of Caesar on behalf of your adopted country? I hear that you Athenians have made Pompey very angry because of that. He thinks that you have wasted his cash ...” (Att. 6.1.25). The funds were put to use by Herodes (the ancestor of the famous second-century benefactor Herodes Atticus) to construct a new market area in the city, today known as the Roman Agora or the Market of Caesar and Augustus. The market was finished with additional funds of Augustus that were given to Herodes' son Eukles. ${ }^{24}$ Both father and son received honorable mention in the inscription which accompanied the gate of the new market: ${ }^{25}$

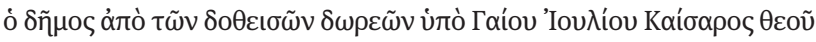

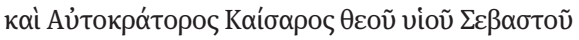

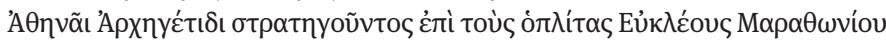

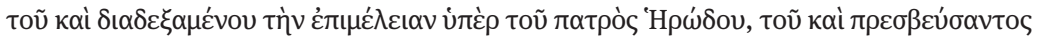

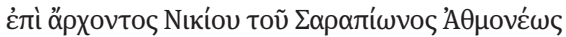

\begin{abstract}
The people, from the gifts given by the god Gaius Julius Caesar and Augustus Caesar, son of a god, to Athena Archegetis (Leader), when Eukles of Marathon, who has taken over the care (of the market) on behalf of his father Herodes, was hoplite general and ambassador, (and) when Nikias of Athmonos, son of Sarapion, was archon.
\end{abstract}

$22 I G \mathrm{II}^{2}$ 1035, line 47 (the so-called "restoration decree"). The most comprehensive study on this inscription is Culley (1973), which also includes an English translation. See also Culley (1975), (1977); Schmalz (2008).

23 Cic. Att. 6.1.25; IG II ${ }^{2}$ 3175. Cf. Hoff (2013), 569.

24 The Market of Caesar and Augustus was finished in the last decade of the first century BCE. The account of Cicero on Herodes of Marathon and the market is extensively discussed in Rawson (1985). Cf. Habicht (1995), 330-331. On the Market of Caesar and Augustus, see also Hoff (2013), 569-570.

$25 I G \mathrm{II}^{2} 3175$, lines 3-4. 
The initiative to seek another sponsor thus seems to have come from the Athenians themselves, in this case from Herodes of Marathon. Rumor was that Pompey was angry with the Athenians for this, probably because he figured that Caesar was trying to gain their support in the inevitable conflict between the two. ${ }^{26}$ If this was the case, Caesar did not succeed in doing so, as the city would still support Pompey in the Battle of Pharsalos two years later (in 48). However, it was Caesar who emerged as victor, and after the battle, Athens sent a delegation to the victorious general (Cass. Dio 42.14). Whereas Sulla had punished Athens severely for its unfaithfulness, Caesar offered amnesty, supposedly only rebuking the Athenians instead by asking them: "How often will the glory of your ancestors save you from self-destruction?” (App. B Civ. 2.88). The Athenians came to terms with their narrow escape, and dedicated at least two statues to Caesar on the

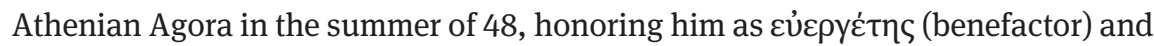
$\sigma \omega \tau$ tń (savior). ${ }^{27}$ A portrait head, now in the National Archaeological Museum in Athens, might represent Julius Caesar because of its style and likeness in physiognomy to Caesar's Tusculum/Turin type. ${ }^{28}$ If so, the portrait head is best dated between 48 and 44, hence in agreement with the statue dedications to Caesar on the Agora.

In March 44 Caesar was stabbed to death in the Curia. The principal conspirators were Marcus Junius Brutus and Gaius Cassius Longinus, better known as Brutus and Cassius. In the fall of 44, the two arrived in Athens. ${ }^{29}$ Dio reports that "The Athenians gave them a splendid reception" (47.20.4). Especially Brutus seemed to have made the best out of his stay in Athens, as he devoted himself to

$26 \operatorname{Hoff}$ (1989b), 2; Hoff (2005), 334 with references.

27 Raubitschek (1954), 65-66; SEG 14, 121; Geagan (2011), 146-147, no. H249-250. For the titles of

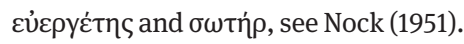

28 Kaltsas (2002), 311, no. 650. On Caesar’s portraits, see Toynbee (1957); Zanker (2009), 301308; Koortbojian (2013), 100-128, and especially Johansen (1987); Fittschen, Zanker and Cain (2010), 19-26. A secure identification is, however, problematic because many portraits from this period "are more or less reminiscent of the features of Caesar," i.e. a Zeitgesicht; see Zanker (2009), 307; Fittschen, Zanker, and Cain (2010), 19. Johansen (1987), 31 excludes Caesar as the figure represented: "It is close in style to the Tusculum portrait, but I doubt that it is in fact a portrait of Caesar. It is, rather, an unknown Greek or Roman from about 50 BC.” If the portrait from Athens does represent Caesar, it would be the earliest known portrait of Julius Caesar with wreath or crown. A portrait from Thasos (Archaeological Museum, Gallery 8), made during the reign of Claudius, depicts an elderly man, possibly Caesar, with corona civica. The general absence of wreaths on portraits of Caesar is surprising since crowns "had become so essential an aspect of his appearance by the end of his life (...) well attested by the ancient authors" and "regularly represented on the coinage", see Koortbojian (2013), 119.

29 On the intermediate years between the Ides of March and the Battle of Philippi, see especially Raubitschek (1957). 
philosophical studies (Plut. Brut. 24) until he joined Crassus again in Smyrna at the end of $43 .^{30}$ The conspiracy of Brutus and Cassius, culminating in the death of Caesar, seems to have reminded the Athenians of a similar act from their own history, for, although the two "were honored by nearly everybody else for what they had done, the inhabitants of this city [Athens] voted them bronze images by the side of those of Harmodius and Aristogeiton, thus implying that Brutus and Cassius had followed their example" (Cass. Dio 47.20.4). The two legendary heroes Harmodius and Aristogeiton were remembered as tyrant-killers, or tyrannicides, for their involvement in the disposal of the Athenian tyrant Hipparchus in 514. ${ }^{31}$ Brutus and Cassius were thus mirrored to Athens' own local heroes, and this connection was made explicit through the dedication of statues of the two side by side with those of the tyrannicides on the Athenian Agora. The tyrannicides, in this context, thus served as an anchor through which the contemporary act of Brutus and Cassius could be contextualized in a traditional Athenian framework.

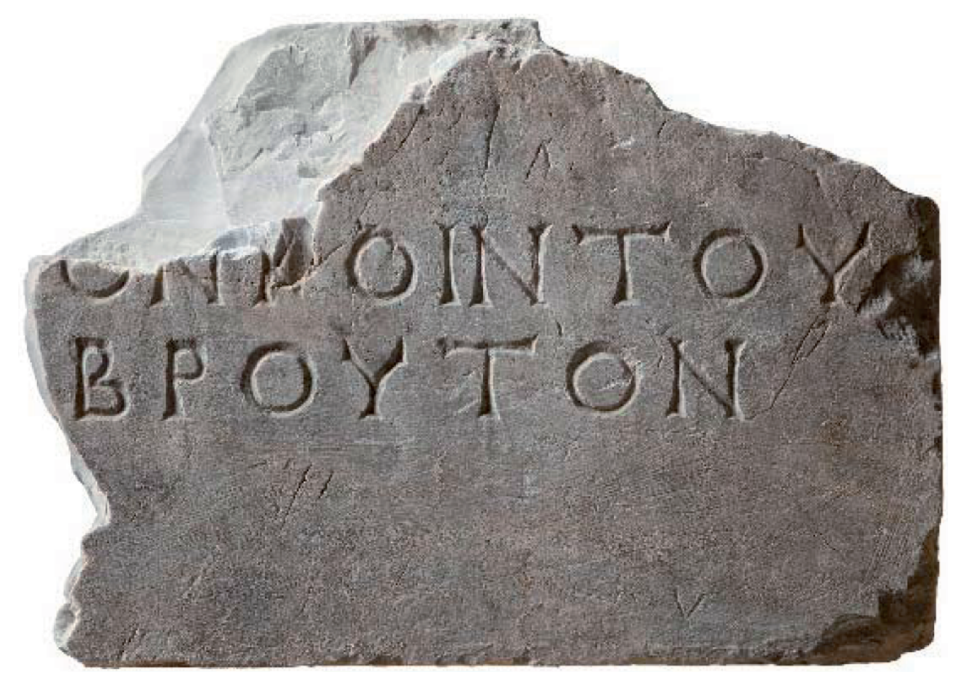

Fig. 1: Statue base with inscription (SEG 17, 75) mentioning Brutus. Found in Athens. Reproduced with permission of the American School of Classical Studies at Athens: Agora Excavations.

30 Habicht (1995), 356.

31 For an account of the act of Harmodius and Aristogeithon, see Thuc. 6.56-59. See also Azoulay (2014), 198-200 for the dedication of statues of Brutus and Cassius. 
Dio's report is supported by the remains of several statue dedications found in Oropos, Delos, and in Athens itself. In Oropos (central Greece), the demos dedi-

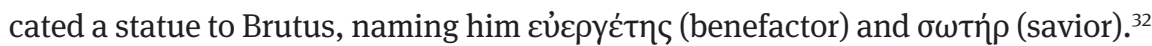
The Athenian community in Delos likewise honored Brutus (and his family) with statues, mentioning several benefactions that Athens had received from him. ${ }^{33}$ Based on these and other parallels, the inscription from Athens (Fig. 1), although fragmentary, can be securely reconstructed as follows: ${ }^{34}$

[ó $\delta \tilde{\eta} \mu \circ \varsigma]$

[Koívtov $\Sigma \varepsilon \rho \beta i ́ \lambda ı]$ ov Koívtov

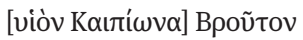

The people (dedicated this statue) to Quintus Servilius Caepio Brutus, son of Quintus.

This was not the first time that influential political leaders were paired with prominent figures from the past in Athens. In the late fourth and early third century BCE, for example, the Hellenistic rulers Antigonos I Monophthalmos and Demetrios I Poliorcetes, were likewise honored with statues side by side with those of the tyrannicides (Diod. Sic. 20.46.2). ${ }^{35}$ The cultural memory of the tyrannicides was once more employed during Sulla's visit to Athens in 84-83, an occasion for which the two famous tyrant-killers were put on the reverses of Athens' silver coins (Fig. 2). ${ }^{36}$ As argued by Habicht and others, these coins unmistakably alluded to the disposal of the Athenian tyrant Aristion by Sulla in $86 .{ }^{37}$ All in all, the reoccurrence of this strategy over time attests to the continuous need to mirror present events to those in the past.

32 IG VII 383; SEG 17, 209; Raubtischek (1959), 16.

33 ID 1613, 1622; Raubitschek (1959), 17; Habicht (1995), 354-356.

34 SEG 17, 75; Raubitschek (1959), 18; Dillon and Garland (2015) [2005], no. 14.25.

35 Mikalson (1998), 75-77; Geagan (2011), 5.

36 Thompson (1961), no. 1165-1172, with revised dating by Mørkholm (1984). The Athenian silver coins in the late Hellenistic Age, known as the New Style silver coinage, have been subject to debate for a long time. Thompson (1961) was the first to collect all the available evidence from hoards in a complementary catalogue. In doing so, she established a relative chronology of Athenian silver which has now been largely neglected in favor of a later chronology. Critique on Thompson's chronology was first published by Lewis (1962), followed by Mattingly (1971 and 1997), Mørkholm (1984), and Habicht (1991). An absolute chronology was established by Mørkholm (1984), 32 for the types minted between 99 and 78/77. Unfortunately, the post-77 types remain problematic. See also Van Alfen (2012), 99-100.

37 Habicht (1995), 311; Azoulay (2014), 195-198; Kuin (2017), 165. 


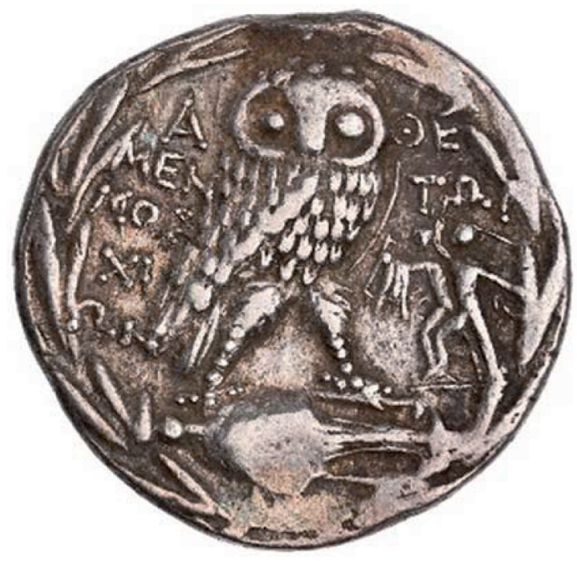

Fig. 2: Reverse of Athenian tetradrachm (84-83 BCE), with a representation of the Harmodius and Aristogeiton statue in the right field. Reproduced with permission of American Numismatic Society.

In October 42, Brutus and Cassius were defeated at Philippi (Macedonia) by Mark Antony and Octavian. It remains unclear whether Athenian soldiers actually participated in the battle. Nevertheless, Athens once again ended up on the losing side in one of Rome's civil wars. ${ }^{38}$ While Octavian returned to Italy, Mark Antony remained in Greece (Plut. Ant. 23.1) and set sail for Athens.

In the years between the Battle of Philippi and the Battle of Actium, Antony visited Athens at least four times. The city even served as his headquarters between 40 and 36, during which he was accompanied by his newly-wed wife Octavia (Octavian's sister). In examining Antony's behavior towards Athens, a pattern can be observed. Like Caesar, Antony offered amnesty to the Athenians (Plut. Ant. 23.2; cf. App. B Civ. 5.7). Like Brutus, he seemed to have engaged with Athens' cultural life (Plut. Ant. 23.2, 33.4, 57.1; cf. App. B Civ. 7.6), and even wished to be addressed as $\varphi \iota \lambda \alpha \theta$ ńvaıs (friend of Athens) (Plut. Ant. 23.2). And lastly, like Pompey, he supported Athens (economically), for when in the spring of 41 an Athenian delegation came to him, he gave them the islands and territories of Aegina, Icos, Ceos, Sciathos, and Peparethos (App. B Civ. 5.7). Furthermore, Antony might have been initiated into the Mysteries of Eleusis (Plut. Ant. 23.2).

The Athenians responded accordingly by bestowing several honors onto Antony and his associates. Among those associates were L. Marcius Censorinus, proconsul of Macedonia between 42 and 40 ( $I G \mathrm{II}^{2}$ 4113), L. Munatius Plancus,

38 Habicht (1995), 356. 
consul in 42 ( $I G \mathrm{II}^{2}$ 4112), C. Cocceius Balbus, consul in 39 (IG $\mathrm{II}^{2}$ 4110), and Antony's freedman M. Antonius Aristocrates (Plut. Ant. 69.1; IG II ${ }^{2}$ 3889). ${ }^{39}$ Furthermore, Antony's wife Octavia, for whom the Athenians seemed to have developed a fondness (Plut. Ant. 57.1), was also honored, as is apparent from an inscription on an altar from the Agora which was dedicated to both Antony and Octavia: ${ }^{40}$
[A]

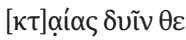
$[\tilde{\omega} v \varepsilon] \cup \beta \varepsilon \rho \varepsilon \tau \tilde{\omega} \nu$

To Antonius and Octavia, both gods and benefactors.

Antony himself was honored as the (new) god Dionysos both in Athens as well as elsewhere in the East, for example in Ephesus (Plut. Ant. 24). Seneca the Elder records that "the Athenians came to him on his arrival with their wives and children, and saluted him as Dionysus” (Suas. 1.6; cf. Cass. Dio 48.39.2, 50.5.3). Furthermore, the Panathenea festival of 38 was celebrated in honor of "Antonius, the new god Dionysos," as an inscription concerning the ephebeia records (IG II ${ }^{2}$ 1043, lines 22-23). Who initiated this divine association remains unsure. The fact that Dionysos was already known amongst the Athenians, not least as the bringer of prosperity and new life, would have provoked positive and familiar associations..$^{41}$ During the Anthesteria spring-festival, for example, the Athenians celebrated the arrival and sacred marriage of Dionysos with the wife of the kingarchon of Athens, effectively making Dionysos the king of Athens. ${ }^{42}$ A slightly adapted form of this ritual was perhaps also performed upon Antony's arrival in Athens, for after mentioning that the Athenians greeted Antony as Dionysos, Seneca records that "they [the Athenians] went on to say that they were offering him their Minerva [Athena] in marriage, and asked him to marry her" (Suas. 1.6). Furthermore, Dionysos' mythological conquest of Asia, and his triumphal return,

39 Antony's freedman apparently maintained a position of influence after the Battle of Actium, see Balzat and Millis (2013).

40 Raubitschek (1946), 149. As observed by Kajava (1990), Roman women, most of them wives of the governors, were almost exclusively honored in combination with their husband in the Greek East; the dedication to Octavia stands in line with this tradition. Yet none of these dedications honor Roman women explicitly in a divine way. Therefore, Octavia was the first Roman woman to be honored with a divine status in the Greek East.

41 Strootman (2014a), 243-246, (2014b), 337, n. 24.

42 Though it is unclear if the Anthesteria festival was continuously celebrated, later sources (second and third century CE), concerned with the participation of the children in the festivities, mention the festival, see Beaumont (2012), 70. 
made him particularly suitable for Hellenistic rulers who aspired to wage war in the East to identify with. ${ }^{43}$ Examples include Demetrios I Poliorcetes (early third century) and Mithridates VI of Pontus (early first century), who were both honored as "the new god Dionysos" in Athens. ${ }^{44}$ Antony's authority and wish to expand Roman rule into Parthian territory could then have been presented in a highly traditional way. In any case, the divine titulature would have associated Antony in the guise of a well-known deity whose arrival symbolized prosperity and new life. ${ }^{45}$

Numismatic evidence likewise demonstrates the connection drawn between Antony and Dionysos. The Athenian coins are often characterized as traditional, as they tend to depict Athena on the obverse and an owl on the reverse. There are of course some variations with, for example, Zeus, Apollo, and Poseidon (for the latter, see above) on the obverse. However, it is remarkable that during Antony's stay in Athens, its mint started to strike Dionysos on the obverse, and a bust of Athena or a standing Athena on the reverse. ${ }^{46}$ This could just be a coincidence. However, when we take into account the historical development of Athens' bronze mint, it becomes apparent that this was the first and only appearance of Dionysos on Athenian bronzes (at least until the reign of Hadrian). Three coin types, dated between 39 and 37 (hence coinciding with Antony's stay in Athens), of which at least 102 specimens have been preserved, are known from the excavations of the Athenian Agora (see Fig. 3). ${ }^{47}$ These coin types correspond to several emissions from Pergamon and Ephesus. Some of this latter group show Antony in Dionysic style (with an ivy-wreath) on the obverse and a Dionysic chest (cistophorus) surmounted by a bust of Octavia on the reverse. ${ }^{48}$ Other variations show Antony and Octavia conjoined on the obverse and a standing Dionysos on the cistophorus on the reverse. ${ }^{49}$ These parallels strongly suggest that the Athenians likewise used their mint to seek a connection with Antony.

43 Versnel (1970), 251-252; Strootman (2014b), 334.

44 Zanker (1988), 46-47; Habicht (1995), 359, (1997), 12; Mikalson (1998), 300-301; Rödel-Braune (2010), 101. For more examples, see Versnel (1970), 252. For Dionysos as a royal icon in the Hellenistic age, see Strootman (2017).

45 Strootman (2014a), 243-246.

46 Kroll (1993), 102-103, no. 140-142.

47 Kroll (1993), 85, 102-103.

48 BMC II, 133-134.

49 BMC II, 135-137. 


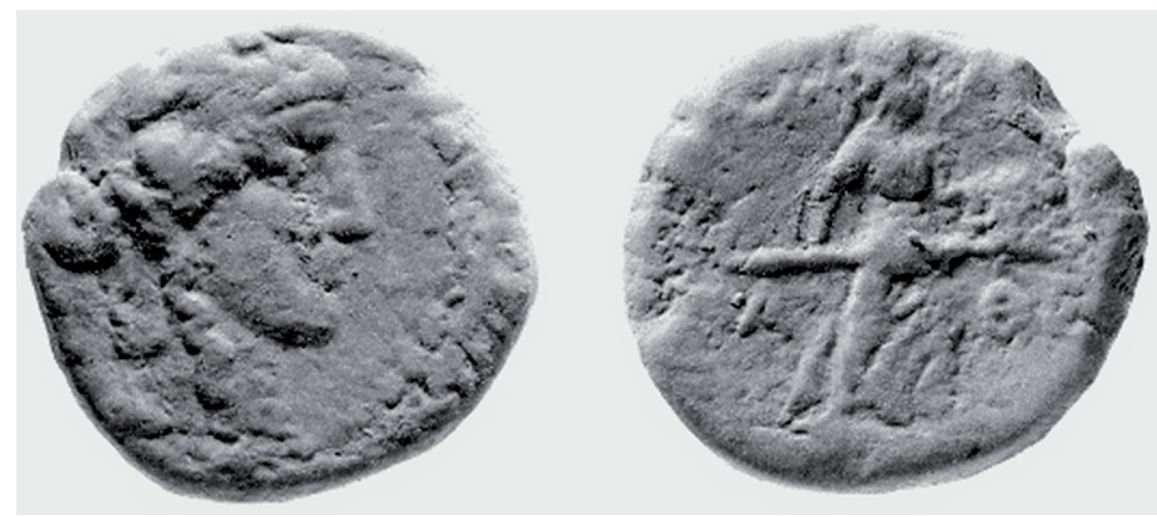

Fig. 3: Athenian bronze coin (39-37 BCE), showing the head of a youthful Dionysos on the obverse. Reproduced with permission of the American School of Classical Studies at Athens: Agora Excavations

In 31, the forces of Octavian and Marcus Agrippa defeated those of Antony and Cleopatra at Actium. Again, we do not know if the Athenians actually participated in the fighting, but up until the battle their city surely belonged to Antony's territory. As mentioned above, when news reached Athens of Octavian's victory, the mood might have been uneasy. For the third time in a row, the Athenians were dependent on the mercy of a Roman ruler. Athens' worry might have been strengthened upon receiving news that a Roman ship from Asia Minor had departed: Octavian was on his way to Athens.

Our sources are ambiguous regarding Octavian's behavior towards Athens. On the one hand, the future emperor seems to have imposed sanctions on Athens; he took away Athens' control over the territories of Aegina and Eretria, and forbade the city to sell its citizenship, which was an important source of revenue for the city (Cass. Dio 54.7). Dio understandably argues that Octavian might have imposed these sanctions to punish the Athenians for their support of Antony. ${ }^{50}$ However, Dio also remarks that "the thing which had happened to the statue of Athena was responsible for this misfortune; for this statue on the Acropolis, which was placed to face the east, had turned around to the west [to Rome] and had spat blood" (ibid.). ${ }^{51}$ Dio's report seems confirmed by Plutarch who mentions

50 On this notion, see also Morales (2017), 150, arguing that Augustan interventions in Athens should "be interpreted as an attempt to obliterate the memory of Antony."

51 Hoff has argued that the Acropolis incident should be placed in the context of anti-Roman sentiment in the city. Although anti-Roman sentiment might indeed have been conceivable in the context of the Roman civil wars, the conclusion that "one can safely assume that there was a 
that Octavian, now named Augustus, withheld from visiting Athens in 21 because "the Athenian people had committed some offense;" instead, he preferred to spend the winter of that year on Aegina (Mor. 207F). ${ }^{52}$

On the other hand, Plutarch mentions that Octavian visited Athens right after the Battle of Actium, making "settlement with the Greeks" and distributing "the grain, which was left from the war, among their cities” (Ant. 68.4). Following a suggestion made by Graindor, Hoff has convincingly argued that a surviving lead token was originally one of the many issued in ca. 31 to be exchanged for rations of grain. ${ }^{53}$ The surviving token (Fig. 4) depicts a young laurel-crowned Apollo (a reference to Octavian) and a six-rayed star (a reference to Caesar's apotheosis). ${ }^{54}$ The association of Apollo with Octavian is substantiated by the inscription Koĩ| $\alpha \alpha \rho$ (Caesar) above the head of Apollo. ${ }^{55}$ Since Octavian is referred to as

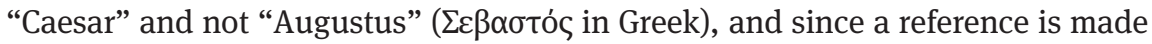
to Caesar's apotheosis, the token should date before 27 and after 44 respectively. The association between Octavian and Apollo seems to have been picked up by the Athenians, who, in addition to honoring Octavian as savior and benefactor (see below), dedicated a statue of Octavian in 21-20 (by then Augustus) as either

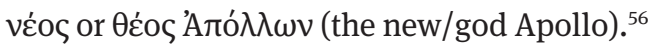

considerable anti-Roman feeling among the general [Athenian] populace" is best left to speculation (Hoff 1989a, 269, cf. Walker 1997, 68; Spawforth 2012, 81-82). The theory can be contrasted to Borg (2011), 214: "No general hostility towards the Romans has ever been recorded at Athens, quite differently from Ephesus."

52 For a discussion on when this event took place, see Hoff (1989a), 268, with references.

53 SEG 42, 219; Numismatic Museum of Athens, inv. no. NM 7485; Rostovtzeff (1903), no. 5; Graindor (1927), 37-38, n. 2, 118; Hoff (1992). Normally, tokens such as these could serve a variety of purposes, for example, as entry tokens for political assemblies, religious festivals, or theater events (Lang and Crosby 1964, 76-78). A token made for events such as these "were usually provided with an inscription or mark that designate its use." The absence of such a reference on the surviving token indicates that that it was probably used in exchange for free gifts, see Hoff (1992), 224 with references.

54 On the assimilation of Octavian with Apollo, see Zanker (1988), 44-53; Lange (2009), 39-46 with references. On the association of a six-rayed star with Caesar, see Bardill (2012), 42-43 with references; also on coins, see Weinstock (1971), 370-384.

$55 S E G$ 42, 219. On the association of Augustus with the name Koĩ $\sigma \alpha \rho$ on early provincial coinage, see Burnett (2011), 12.

56 SEG 29, 167. Both Claudius and Nero are also honored in Athens as (new) Apollo, see $I G \mathrm{II}^{2}$ 3274 (Claudius); IG II² 3278, 3182; SEG 32, 252; SEG 44, 165; SIA 1, 60 (Nero). 


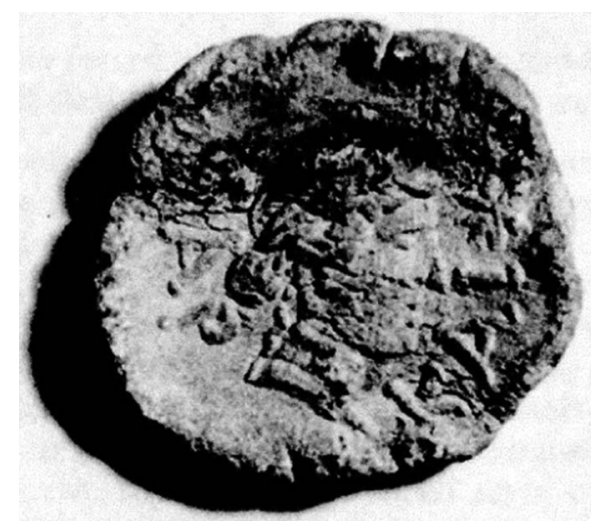

Fig. 4: Athenian lead token, showing the head of Apollo and a six-rayed star. Reproduced with permission of M. Hoff.

In addition to distributing grain, Octavian also let himself be initiated into the Eleusinian Mysteries twice (Suet. Aug. 93; for the second time in 19: Cass. Dio 4.9.7-10). Both events, the distribution of grain and the initiation into the Mysteries, were distinctively linked with one another as they revolved around the themes of fertility and prosperity. In the second century CE, the emperor Hadrian followed in Augustus' footsteps when he too initiated himself in the Mysteries and then distributed grain. ${ }^{57}$ Lastly, as mentioned above, Octavian continued the economic support which had initially been provided by his adoptive father for the construction of a new market area in the city (the Market of Caesar and Augustus). ${ }^{58}$

Likewise, the Athenians honored the new Roman leader. One of the earliest dedications to Octavian comes from Eleusis, where a large two-course monument (measuring about five meters on each side) was built to hold two statues. The discovery of two inscriptions on this monument by Vanderpool has revealed that these statues were dedicated to Octavian and his wife Livia..$^{59}$ The inscriptions read:

57 BMC III, 1094 (minted in Asia Minor) commemorates the initiation of both emperors as the coins depict a portrait of the emperor Augustus on the obverses, and the emperor Hadrian on the reverses, holding ears of corn. As such, the coins explicitly mirror Hadrian with Augustus.

58 IG II ${ }^{2}$ 3175; Hoff (2013), 569, 572.

59 Vanderpool (1968), 7-9. Cf. SEG 24, 212; Clinton (2005), no. 296. 


\author{
ò $\delta \tilde{\eta} \mu \circ \varsigma$

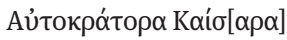

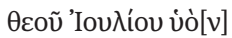 \\ тòv $\dot{\alpha} \tau o \tilde{~} \sigma \omega \tau \tilde{\eta}[\rho \alpha]$

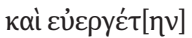

The people (dedicated this statue) to its savior and benefactor imperator Caesar, son of the god Julius

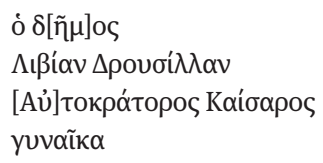

The people (dedicated this statue) to Livia Drusilla, wife of imperator Caesar.

What is especially noteworthy about the Eleusis-dedication is the fact that it must have been constructed somewhere between 31 (the Battle of Actium) and 27 (when Octavian became known as Augustus), indicating Athens' quick response to the change in rulership. It is tempting to connect the dedication with Octavian's visit to Eleusis shortly after the Battle of Actium when he was initiated into the Mysteries. In addition to being honored as "new Apollo" (see above), surviving dedications from the Athenian Agora show that Octavian/Augustus is mainly honored as "son of the god Julius Caesar," and as $\sigma \omega \tau$ tŕ $\left(\right.$ savior). ${ }^{60}$ A portrait head, made from Pentelic marble from Mt. Pentelikon (north of Athens), which is now in the National Archaeological Museum of Athens (Fig. 5), shows Augustus in his main portrait type (Prima Porta type), and can possible be connected to one of these dedications. ${ }^{61}$ The head, dated by most in the early reign of Augustus, ${ }^{62}$ roughly follows the Roman prototype, yet the plasticity of the locks, the shape of the face, the full lips, and the deep-set eyes are reminiscent of Hellenistic portraiture. Similar "free imitations" of the Prima Porta type are known for example from Samos and Aphrodisias, and presented Augustus in a familiar Hellenistic fashion. ${ }^{63}$ Whether the head was consciously modeled to achieve this, or the result of a mixture of Roman models with Athenian sculptural traditions, the style of the

60 IG II $2227-3228$; SEG 18, 73, 75-79 (son of a god); IG II² 3173; SEG 29, 168 (savior).

61 Athens, National Archaeological Museum, inv. no. 3758.

62 Hoff (1988), 113, n. 71; Boschung (1993), 142, no. 72, suggesting a date between 27 BCE - 14 CE, and Kaltsas (2002), 316-317, no. 661, dating the portrait "about 20 BC.”

63 Mayer (2010), 116. Cf. Boschung (1993), 173, no. 156. On the adjustment of Roman imperial portraits for communication in the East, see Zanker (1983). On the system of commissioning and distributing imperial portrait types, see still Fittschen (1971), esp. 222. 
head would express a sense of familiarity, and as such could have aided in the recognition and accommodation of Roman rule.

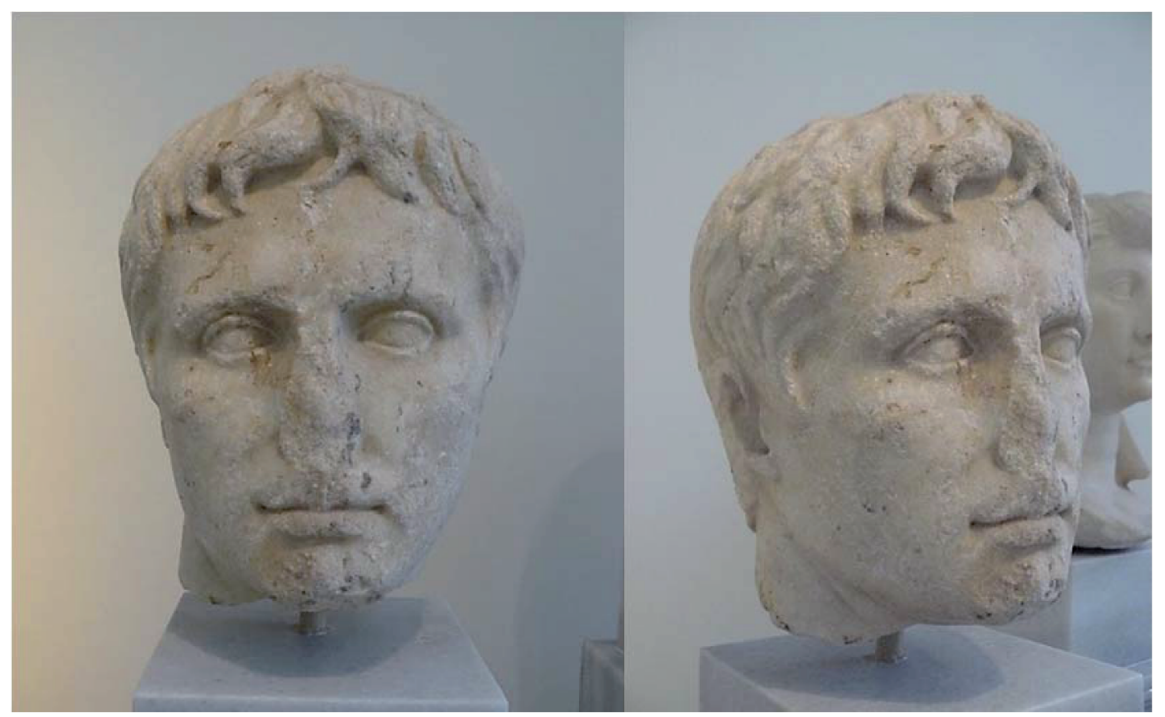

Fig. 5: Portrait of emperor Augustus (Athens, National Archaeological Museum, inv. no. 3758). Prima Porta type. Found in Athens. Photos by author.

Before making some concluding remarks on how Roman leaders and the Athenian elite negotiated a common ground in the first century BCE, it is worthwhile to return to the Acropolis, where the (in)famous incident of Athena's statue had supposedly taken place. Additional material evidence on the site can aid us in discovering a process that is in many ways exemplary of the mechanisms we have seen above. This additional material is concerned with two buildings known as the Monument of Agrippa and the Temple of Roma and Augustus, of which the remains can still be found on the hill of the Acropolis (Figs. 6 and 7 respectively). ${ }^{64}$

The pedestal known as the Monument of Agrippa (west of the Propylaia) was originally built in honor of Eumenes II and Attalos II of Pergamon in the early

64 On the Temple of Roma and Augustus, see Binder (1969); Hoff (1996); Camp (2001), 187-188; Whittaker (2002); Rose (2005), 50-53; Kantiréa (2007), 124-129, 175-177; Thakur (2007); Dally (2008); Fouquet (2012); Morales (2017). On the Monument of Agrippa, see Dinsmoor (1920) (abstract); Alcock (1993), 197; Habicht (1995), 359-360; Camp (2001), 189; Shear (2007), 244 with references; Keesling (2010), 307-308. 
second century BCE, and would have held a bronze quadriga (a chariot drawn by four horses) with portraits representing the kings of Pergamon (Paus. 1.22.4). Before it was dedicated to Agrippa, the pedestal might have served as a base to hold statues of Antony and Cleopatra. This is suggested by Plutarch, who explicitly refers to the monument in connection to Antony (Ant. 60), and also by Cassius Dio, who mentions "statues of herself [Cleopatra] and Antony in the guise of gods, which the Athenians had placed on their Acropolis" (50.15.3). ${ }^{65}$ The monument can be linked with more certainty to Marcus Agrippa-Octavian's close companion and most important general. An inscription on the west side of the monument (Fig. 6) reveals the following: ${ }^{66}$

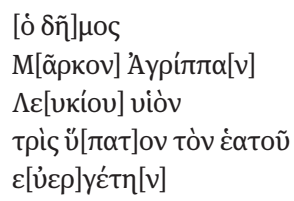

The people (dedicated this monument) to its benefactor Marcus Agrippa, son of Lucius, consul for the third time.

Since Agrippa held his third consulship in 27 (together with Octavian), the dedication ought to be dated after that year and probably before Agrippa's visit to the city around $16 .{ }^{67}$ Considering the fact that Agrippa, like Eumenes, was the sponsor of a large building project in Athens, it is reasonable to think that the spectators were meant to link the two together. Whereas Eumenes had funded a stoa set against the south slope of the Acropolis, Agrippa sponsored the construction of a large theater-building (odeon) on the Agora (finished around 16-14). ${ }^{68}$ The rededication of the pedestal shows that the Athenians sought to honor Agrippa in the same way they had honored previous benefactors. ${ }^{69}$ At least two more dedicatory inscrip-

65 Both stories are, however, primarily used by the ancient authors to illustrate the gods' favor for Octavian, because the statues of Antony and Cleopatra were destroyed in a storm just before the Battle of Actium.

66 IG II 4122.

67 On Agrippa's visit, see Spawforth (2012), 59.

68 On Agrippa as sponsor of the theater-building, see Schmalz (1994), 89-90; StefandidouTiveriou (2008), 23; Spawforth (2012), 59-60.

69 Shear discusses the complexities of such rededications. She highlights the fact that a certain dedication was often chosen so it might link the original dedication to the reconfiguration (Shear 2007, 222-223, 225). This can also be seen as a strategy of highlighting Athens' self-importance (Shear, ibid. 242-246), as such dedications presented Roman benefactors in a traditional Athenian way. On this practice, see the recent work of Moser (2017). 
tions have withstood the test of time: one from the same area as the monumental pedestal and in similar formulaic style, and the other in modern context southwest of the Agora. ${ }^{70}$

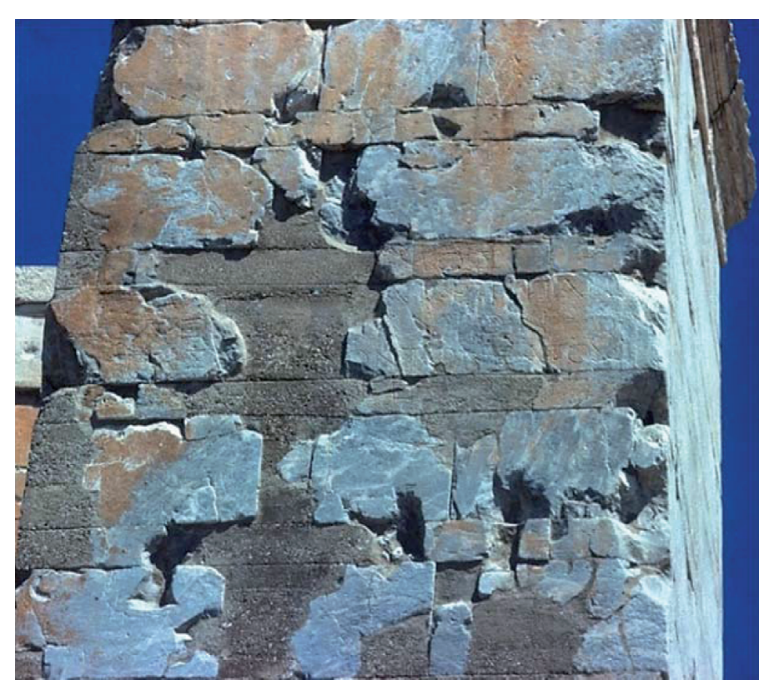

Fig. 6: West side of the remains of the Monument of Agrippa. Reproduced with permission of the American School of Classical Studies at Athens: Agora Excavations

On the other side of the Acropolis, the remains of a circular temple (tholos) dedicated to Augustus and the goddess Roma can still be located, although it is probably not in situ. Amidst these remains, a fragment of the upper part of the temple can be found (Fig. 7), one that carries the following inscription: ${ }^{71}$

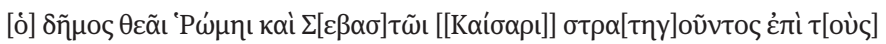

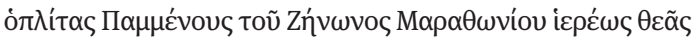

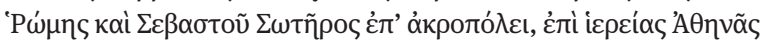

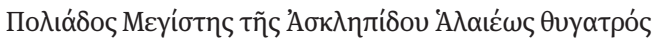

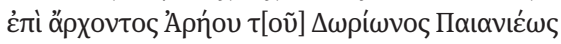

70 IG II 24123 and Geagan (2011), 227-228, no. H417 respectively.

$71 \mathrm{IG} \mathrm{II}{ }^{2}$ 3173. The inscription mentions a joint cult of Augustus and Roma. The cult of the latter seems to have been present in Athens from at least the mid-second century BCE onwards (although the exact location where this cult was practiced remains unknown), see Whittaker (2002), 30. 
The people (dedicated this monument) to the goddess Roma and Augustus Caesar (at the time that) Pammenes, son of Zenon of Marathon, was hoplite general and priest of the goddess Roma and Augustus savior on the Acropolis, (and) Megiste, daughter of Askepiades of Halai, was priestess of Athena Polias, (and) Areos, son of Dorion of Paiania, was archon.

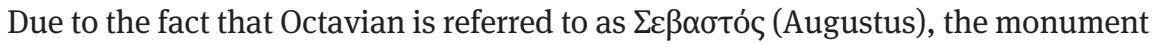
must have been constructed after 27. Furthermore, the archonship of Areos can be dated before 17, allowing us to date the construction of the monument between 27 and $17 .{ }^{72}$ The dedication by the $\delta \tilde{\eta} \mu \circ \varsigma$ and the title of $\sigma \omega \tau$ tn $\rho$ are common features that we have seen before regarding honors to Roman leaders. ${ }^{73}$

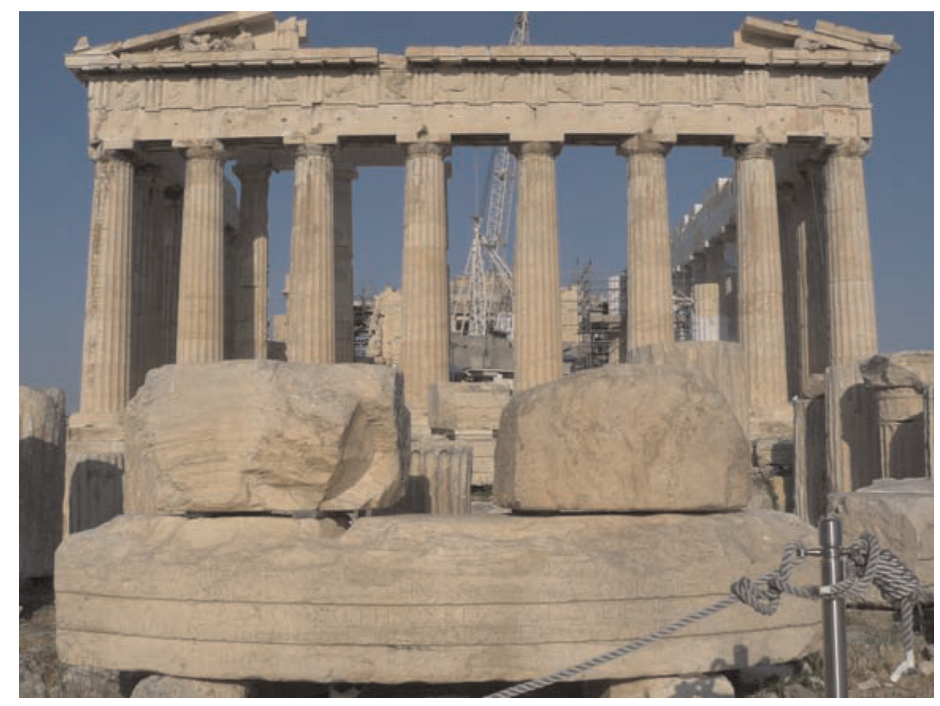

Fig. 7: The remains of the Temple of Roma and Augustus in front of the east entrance of the Parthenon. Photo by author.

72 Whittaker (2002), 26-27. The construction of the monument might be connected to the construction of similar temples in Pergamon and Nicomedia, sanctioned by Octavian himself in 30/29 (Cass. Dio 51.20.6-7), which can be seen as evidence for a date closer to 27 than 17 . This should, however, not be seen as evidence for a deliberate politically motivated Augustan building program, as rightly addressed by Raja (2012), $113 \mathrm{n} .432$.

73 Morales has argued that the title of $\sigma \omega \tau$ tr might have linked Augustus to Apollo because the latter was also called "savior" in an Athenian decree of 129-128 BCE. See Morales (2017), 145 with references. This theory can be contrasted to that of Spawforth (2012), 107 who argued that the title referred to Augustus' recent Parthian success. 
The current location of the remains of the Temple of Roma and Augustus on the longitudinal axis with the Parthenon is often treated as the exact location of the original site. ${ }^{74}$ Through a careful examination of the archaeological records, Binder and others have, however, questioned this assumption. ${ }^{75}$ Still, the concentration of finds on the Acropolis indicate that the temple stood in close proximity of the Parthenon and the Erechtheion. ${ }^{76}$ As will be demonstrated below, this spatial context is, in addition to the architectural style of the building, crucial to the temple's significance and meaning.

The Temple of Roma and Augustus was erected from Pentelic marble, like much of the other buildings on the Acropolis (such as the Parthenon, the Erechtheion, and the Temple of Athena Nike). The temple's Ionic columns were connected to the local context in particular, as they were almost exact replicas of those of the nearby Erechtheion (named after one of Athens' legendary kings). Furthermore, the buildings and decorations near the newly-build temple were all important expressions of Athens' history and identity. In close proximity of the temple loomed the Parthenon, of which its pediments depicted Athena's birth and the contest between her and Poseidon (Paus. 1.24.5). The nearby Erechtheion, which stylistically resembled the temple of Roma and Augustus, supposedly housed Athens' most important relics of the past (e.g. the famous olive tree given by Athena, the old wooden cult statue of Athena Polias, and tombs of early kings). ${ }^{77}$ This "memory theater"78 was deemed an appropriate context by the Athenians to honor Roma and Augustus.

At the same time, the Acropolis was also what has been referred to as a "field of victory," commemorating the triumph of the Greeks over the Persians. ${ }^{79}$ Besides the fact that the Parthenon was in itself a victory monument, its metopes on the eastern façade depicted a Gigantomachy, which represented the triumph of civilization (the Greeks) over barbarism (the Persians). In between the metopes, the famous shields of Alexander the Great, those that he took as spolia from the Persians after his victory at Granikos in 334, would have evoked similar cultural memories of Greek triumph. Lastly, the freestanding statues of fallen Persians, known as the Smaller Attalid Group, which were dedicated by Attalos I of Pergamon (third century BCE), made the cultural memory of Greek triumph

74 Schmalz (1994); Hoff (1996); Hurwitt (1999); Rose (2005); Kantiréa (2007), 125-127; Thakur (2007); Dally (2008); Morales (2017).

75 Binder (1969), 22-33; Fouquet (2012), 54-55; Burden (1999), 63-64.

76 Binder (1969), 22-33, 132 (I). Also Fouquet (2012), 54-55.

77 Thakur (2007), 119-122. Cf. the description by Paus. 1.26.5-7, 1.27.1-3 of the Erechtheion.

78 Alcock (2002), 54 n. 29.

79 E.g. Hoff (1996), 193; Hurwit (1999), 281; Rose (2005), 50-51. 
strikingly explicit (Paus. 1.25.2). As a result, it is probable that the Temple of Roma and Augustus was placed in this field of memory because of Augustus' contemporary victory (although diplomatic) over the Parthians in $20 .{ }^{80}$ The cultural memories associated with the Acropolis would have provided an appropriate context to link current events to the Greek past. This theory is supported by the fact that a similar strategy was employed in the mid-first century CE when a dedication to emperor Nero was inscribed on the east façade of the Parthenon,

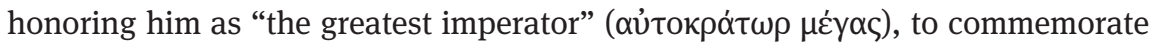
his victory over the Parthians. ${ }^{81}$

The Temple of Roma and Augustus was thus both architecturally and spatially anchored in the context of Athens' cultural and religious landscape. In addition, the placement of the temple in the context of the Acropolis around the time of Augustus' Parthian settlement established a strong connection between present and past. The rededication of the Hellenistic pedestal to Agrippa additionally demonstrates that the practice of euergetism continued into the early Augustan Age, and that past associations to buildings could aid in the contextualization of present events. ${ }^{82}$ From this point onwards, it would primarily be the

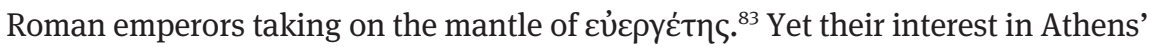
past should, in addition to whatever propagandistic purposes it might have served, also be understood from the angle of finding a common ground through which power and influence was negotiated between ruler and ruled.

In the first century BCE, Athens was at the center of Rome's civil wars. Almost all of the important political figures in these wars visited Athens: Pompey, Caesar, Brutus, Cassius, Antony, Octavian, and Agrippa. This paper has argued that a dialogue was initiated between these Roman leaders and the Athenian elites in which power and influence were negotiated. In search for common ground, anchors were used to present new events in ways that people knew and understood. The socio-political practice of euergetism was as one of the ways through

80 Schmalz (1994), 7-42; Rose (2005), 50-53. Both link the Temple of Roma and Augustus, due to its circular shape, to the Temple of Mars Ultor, which was depicted in similar circular shape on Spanish and Pergamene coins. See also Morales (2017), 149-150. However, this monument was never actually built and the coin series was limited in circulation. The theory of Schmalz and Rose can be contrasted to Thakur (2007), 115.

81 IG II 3277 , see Carroll (1982).

82 Also Morales (2017), 144.

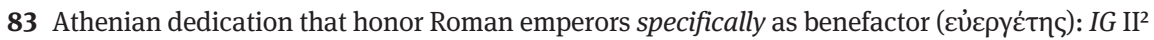

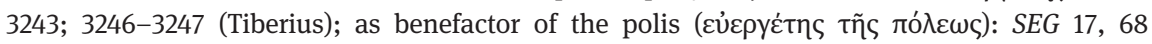
(Tiberius); IG II 3267 (Caligula); IG II² 5175; 5177-5178; SEG 19, 235, SEG 23, 130 (Claudius); and as

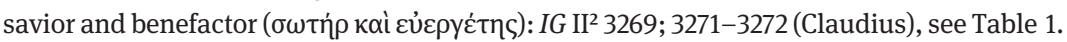


which this was achieved. As a result, Roman leaders followed in line with Hellenistic benefactors of Athens, who repeatedly adorned Greek cities such as Athens to improve their ties to the traditional centers of Greek culture. Although, over time, acts of euergetism would not necessarily have reminded one of just Hellenistic predecessors, they would still have alluded to a deep-rooted expectation of how a foreign leader should behave in Athens. This anchor proved to be successful. The Athenians recognized Roman leaders as benefactors on their part and used corresponding honorary epithets in statue dedications to them. Another recurrent way in which Roman leaders were presented in a traditional framework was by their assimilation with well-known deities such as Dionysos or Apollo.

Additional cognitive footholds used in search for a common ground were found in the material manifestations of Athens' past and culture. This has, for example, become apparent from the dedication of statues of Brutus and Cassius beside those of Harmodius and Aristogeiton, which "translated" the formers' deed in familiar terms. The rededication of a Hellenistic pedestal to Agrippa, too, demonstrates that past associations to monuments were used to accommodate contemporary events. Furthermore, the case of the Temple of Roma and Augustus has demonstrated that even when new commemorative buildings were erected, existing spatial contexts and/or styles could be turned to in order to anchor new situations or events in a traditional framework.

The results of this paper have thus shown that even before the imperial age, Athens' past and culture were turned to as a shared field of references to find common ground between Rome's leaders and Athens. Inquiries into other cities in Greece yield similar results, and should further encourage scholars to contest the assumed Augustan agency behind such engagements with the Greek past and culture around the change of the millennium. ${ }^{84}$ In fact, we should even consider the possibility that local projections on Roman leadership might occasionally have influenced central imagery. In Rome, for example, the famous victory of the Athenians over the Persians at the Battle of Salamis was reenacted on occasion of Gaius Caesar's departure to the East to fight the Parthians ( $R G$ 23; Cass. Dio 55.10.7)..$^{85}$ The use of such anchors might well have been inspired by the way the Parthian settlement was anchored in Athens almost two decades earlier.

84 E.g. Alcock's inquiry of the Treasury of Minyas at Orchomenos, see Alcock and Cherry (2006) and Alcock (2015), 26-27.

85 On the link between this event in Rome and the Athenian ephebic naumachia, see Newby (2017), 87-88, 93. 
Table 1: Dedications from Athens to the imperial family (Julio-Claudian). Marked references $\left({ }^{\star}\right)$ attest to an official priesthood in the city.

\begin{tabular}{|c|c|c|}
\hline Honoree & Reference(s) & Title(s) (in var.) \\
\hline \multirow[t]{5}{*}{ Augustus } & IG II2 3173; SEG 29, 168 & $\sigma \omega t \eta ́ \rho ~$ \\
\hline & $I G \|^{2}$ 3227-3228; SEG 18, 73, 75-79 & 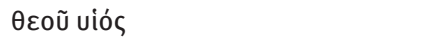 \\
\hline & IG II 3257 & 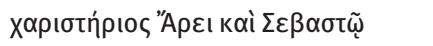 \\
\hline & IG II $3521^{\star} ; 5034^{*}$ & 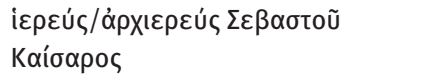 \\
\hline & SEG 29, 167 & 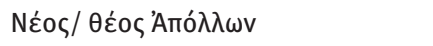 \\
\hline \multirow[t]{4}{*}{ Livia } & SEG 22, 152 & 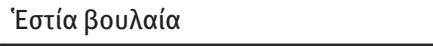 \\
\hline & IG II 3238 & 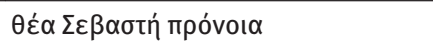 \\
\hline & IG II' 3239; 3241 & 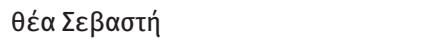 \\
\hline & IG II² 5096* (with Julia Maior) & 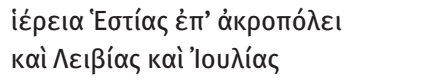 \\
\hline Agrippa & IG II $4122-4123$ & 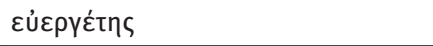 \\
\hline \multirow[t]{2}{*}{ Drusus Maior } & IG II 3249 & 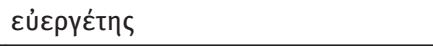 \\
\hline & $I G \|^{2} 1724^{*} ; 1730^{\star}$ & 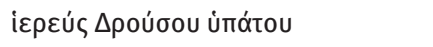 \\
\hline Gaius Caesar & IG $\|^{2} 3250$ & 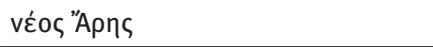 \\
\hline \multirow[t]{2}{*}{ Lucius Caesar } & IG II' 3251 & viós Aủтокра́тороৎ \\
\hline & IG II 3252 & 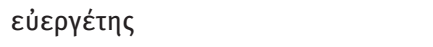 \\
\hline \multirow[t]{5}{*}{ Tiberius } & $I G \|^{2} 3244 ; 3245$ & 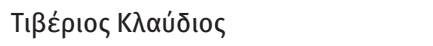 \\
\hline & $I G \|^{2} 3243 ; 3246-3247$ & 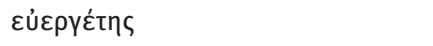 \\
\hline & SEG 17, 68 & 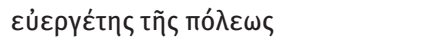 \\
\hline & IG II' 3264-3265; 4209; SEG 17, 68 & $\theta$ éós \\
\hline & Hesperia 4, 58, 21*; IG $\|^{2} 3530^{\star}$ & 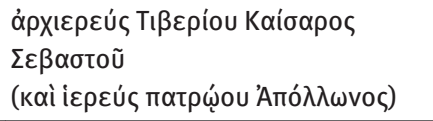 \\
\hline Drusus Minor & IG II' 3257 & 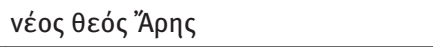 \\
\hline Germanicus & $I G \|^{2} 3258-3260$ & 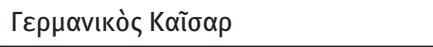 \\
\hline Agrippina Maior & SEG 25, 208 & $\theta \varepsilon ́ \alpha \Sigma \varepsilon \beta \alpha \sigma \tau \eta^{\prime}$ \\
\hline \multirow[t]{2}{*}{ Caligula } & $I G \|^{2} 3267$ & 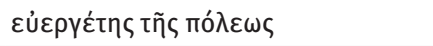 \\
\hline & SEG $34,182^{\star}$ & 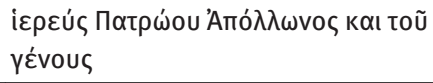 \\
\hline \multirow[t]{2}{*}{ Drusilla } & SEG 34, 180 & 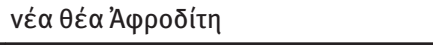 \\
\hline & $I G \|^{2} 3266^{*}$ & 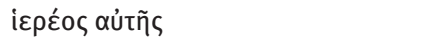 \\
\hline
\end{tabular}


Table 1: (continued)

\begin{tabular}{|c|c|c|}
\hline Honoree & Reference(s) & Title(s) (in var.) \\
\hline Julia Livilla & IG $\|^{2} 5101$ & 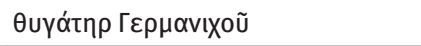 \\
\hline \multirow[t]{5}{*}{ Claudius } & IG II' 3269; 3271-3272 & 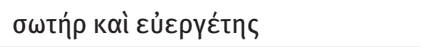 \\
\hline & IG II' 3266; 3268; 3270; 3276 & 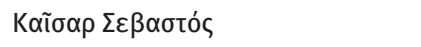 \\
\hline & $I G \|^{2} 3274^{*}$ & 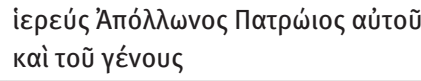 \\
\hline & $\begin{array}{l}I G \|^{2} 5175 ; 5177-5178 \\
\text { SEG 19, 235; } 23,130\end{array}$ & 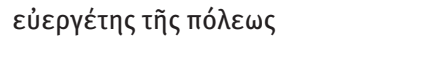 \\
\hline & IG $\|^{2} 3273$ & 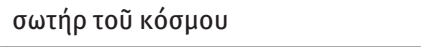 \\
\hline Antonia Minor & IG $\|^{2} 3535^{\star} ; 5095^{\star}$ & 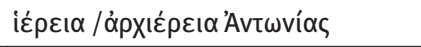 \\
\hline \multirow[t]{3}{*}{ Nero } & $\begin{array}{l}\text { IG II } 3278 ; \text { SEG 32, 252; 44, 165; SIA } \\
1,60\end{array}$ & 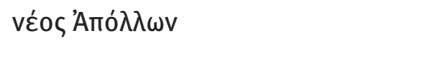 \\
\hline & $I G \|^{2} 3277$ & 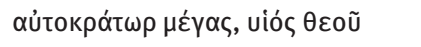 \\
\hline & $I G \|^{2} 3182^{*}$ & 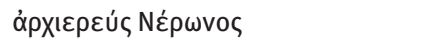 \\
\hline
\end{tabular}

\section{Bibliography}

Alcock, S. E. Graecia Capta: the Landscapes of Roman Greece. Cambridge: Cambridge U. P., 1993.

Alcock, S. E. Archaeologies of the Greek Past: Landscape, Monuments, and Memories. Cambridge: Cambridge U. P., 2002.

Alcock, S. E. and J. F. Cherry. "No greater marvel: a Bronze Age classic at Orchomenos." In Classical Pasts: the classical traditions of Greece and Rome, edited by J. I. Porter, 69-86. Princeton: Princeton U. P., 2006.

Alcock, S. E. "Kaleidoscopes and the spinning of memory in the Eastern Roman Empire." In Cultural Memories in the Roman Empire, edited by K. Galinsky and K. D. S. Lapatin, 24-32. Los Angeles: J. Paul Getty Museum, 2015.

van Alfen, P. G. "The coinage of Athens, sixth to first century B.C." In The Oxford Handbook of Greek and Roman Coinage, edited by W. E. Metcalf, 88-104. Oxford: Oxford U. P., 2012.

Ando, C. Imperial Ideology and Provincial Loyalty in the Roman Empire. Berkeley: University of California, 2001.

Azoulay, V. Les tyrannicides d'Athènes: vie et mort de deux statues. Paris: Editions du Seuil, 2004.

Balzat, J. S. and B. W. Millis. "M. Antonius Aristocrates: provincial involvement with Roman power in the late 1st century B.C." Hesperia 82.4 (2013): 651-672.

Bardill, J. Constantine, Divine Emperor of the Christian Golden Age. Cambridge: Cambridge U. P., 2012. 
Beaumont, L. A. Childhood in Ancient Athens: Iconography and Social History. London: Routledge, 2012.

Binder, W. Der Roma-Augustus Monopteros auf der Akropolis in Athen und sein typologischer Ort. Dissertation. Universität Karlsruhe, 1969.

Borg, B. "Who cared about Greek identity? Athens in the first century BCE." In The Struggle for Identity: Greeks and their past in the first century BCE, edited by T. A. Schmitz and N. Wiater, 213-234. Stuttgart: Steiner, 2011.

Boschung, D. Die Bildnisse des Augustus. Berlin: Gebr. Mann, 1993.

Brophy, E. "Two-for-one: looking at imperial Egyptian statues with Roman features in Egypt." In Current Research in Egyptology 2013: Proceedings of the Fourteenth Annual Symposium, University of Cambridge 2013, edited by K. Accetta, R. Fellinger, P. L. Gonçalves, S. Musselwhite and W. P. van Pelt, 22-33. Oxford: Oxbow, 2014.

Burden, J. C. Athens Remade in the Age of Augustus: a Study of Architects and Craftsmen at Work. Dissertation. University of California, 1999.

Burnett, A. "The Augustan revolution seen from mints of the provinces." Journal of Roman Studies 101 (2011): 1-30.

Camia, F. "The theoi sebastoi in the sacred landscape of the polis. Cult places for the emperors in the cities of mainland Greece." In Im Schatten der Alten? Ideal und Lebenswirklichkeit im römischen Griechenland. 3. Heidelberger Altertumswissenschaftliches Studierendenkolloquium 8.-10. November 2013, edited by J. Fouquet and L. Gaitanou, 9-23. Wiesbaden: Harrassowitz, 2016.

Camp, J. M. 2001, The Archaeology of Athens. New Haven: Yale U. P., 2001.

Carroll, K. K. The Parthenon Inscription, Durham, NC: Duke U. P., 1982.

Clark, H. H. "Communities, commonalities, and communication." In Rethinking Linguistic Relativity, edited by J. J. Gumperz and S. C. Levinson, 324-355. Cambridge: Cambridge U. P., 1996.

Clinton, K. Eleusis: the Inscriptions on Stone: Documents of the Sanctuary of the Two Goddesses and Public Documents of the Deme. Athens: Archaeological Society at Athens, 2005.

Craig, R. T. "Communication theory as a field." Communication Theory 9.2 (1999): 119-161.

Croft, W. "Towards a social cognitive linguistics." In New Directions in Cognitive Linguistics, edited by V. Evans and S. Pourcel, 395-420. Amsterdam: John Benjamins, 2009.

Culley, G. R. The Restoration of Sacred Monuments in Augustan Athens (IG 2/3(2) 1035). Dissertation. University of North Carolina: Chapel Hill, 1973.

Culley, G. R. “The restoration of sanctuaries in Attica: I.G., II2, 1035.” Hesperia 44 (1975): 207-223.

Culley, G. R. "The restoration of sanctuaries in Attica, 2. The structure of IG II2, 1035 and the topography of Salamis.” Hesperia 46 (1977): 282-298.

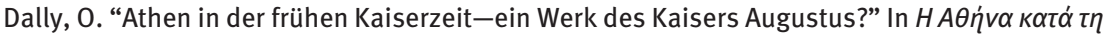

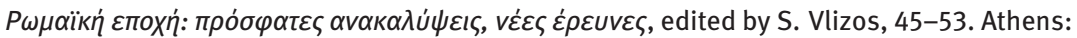
Benaki Museum, 2008.

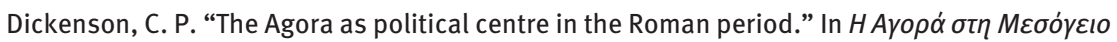

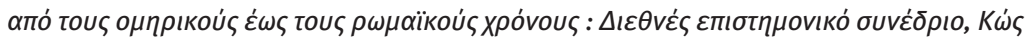

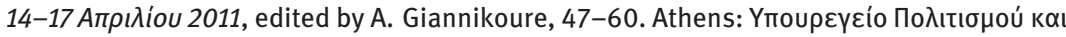

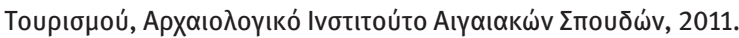

Dickenson, C. P. On the Agora: the Revolution of a Public Space in Hellenistic and Roman Greece (c. 323 BC - 267 AD). Leiden: Brill, 2017.

Dijksta, T. M., I. N. I. Kuin, M. Moser and D. Wiedgenannt, editors. Strategies of Remembering in Greece under Rome (100 BC-100 AD). Leiden: Sidestone, 2017. 
Dillon, M. and L. Garland. Ancient Rome: Social and Historical Documents from the Early Republic to the Death of Augustus. Second edition. New York: Routledge, 2015.

Dinsmoor, W. B. "The monument of Agrippa at Athens." American Journal of Archaeology 24.1 (1920): 83.

Evans, N. "Embedding Rome in Athens." In Rome and Religion: a Cross-disciplinary Dialogue on the Imperial Cult, edited by J. Brodd and J. L. Reed, 83-97. Atlanta: Society of Biblical Literature, 2011.

Fittschen, K., P. Zanker and P. Cain. Katalog der römischen Porträts in den Capitolinischen Museen und den anderen kommunalen Sammlungen der Stadt Rom. Band II: die männlichen Privatporträts. Berlin: de Gruyter, 2010.

Foubert, L. "Vesta and Julio-Claudian women in imperial propaganda." Ancient Society 45 (2015): 187-204.

Fouquet, J. "Der Roma-Augustus-Monopteros auf der Athener Akropolis. Herrscherkult und Memoria «ad Palladis temple vestibulum»?" Thetis 19 (2012): 47-95.

Geagan, D. J. The Athenian Constitution after Sulla. Princeton, NJ: American School of Classical Studies at Athens, 1967.

Geagan, D. J. Inscriptions: the Dedicatory Monuments, Princeton, NJ: American School of Classical Studies at Athens, 2011.

Graindor, P. Athènes sous Auguste. Cairo: Impr. Misr., 1927.

Grimm, G. Kunst der Ptolemäer- und Römerzeit im Ägyptischen Museum Kairo, Mainz: Philipp von Zabern, 1975.

Gruen, E. S. Rethinking the Other in Antiquity. Princeton, NJ: Princeton U. P., 2011.

Gurval, R. A. Actium and Augustus: the Politics and Emotions of Civil War. Ann Arbor: University of Michigan, 1995.

Habicht, C. "Zu den Münzmagistraten der Silberprägung des Neuen Stils.” Chiron 21 (1991): $1-23$.

Habicht, C. Athen: die Geschichte der Stadt in hellenistischer Zeit. Munich: Beck, 1995.

Habicht, C. "Roman citizens in Athens." In The Romanization of Athens: Proceedings of an International Conference held at Lincoln, Nebraska (April 1996), edited by M. C. Hoff and S. I. Rotroff, 9-17. Oxford: Oxbow, 1997.

Hekster, O. J., L. M. G. F. E. Claes, E. E. J. Manders, D. Slootjes, Y. Klaassen and N. de Haan. "Nero's ancestry and the construction of imperial ideology in the early empire.

A methodological case study." Journal of Ancient History and Archaeology 1.4 (2014): $7-27$.

Hekster, 0. J. Emperors and Ancestors: Roman Rulers and the Constraints of Tradition. Oxford: Oxford U. P., 2015.

Hekster, O. J. "Religion and tradition in the Roman Empire: faces of power and anchoring change." Journal of Ancient Civilizations 32 (2017): 13-34.

Hoff, M. C. The Roman Agora at Athens. Dissertation. Boston University, 1988.

Hoff, M. C. "Civil disobedience and unrest in Augustan Athens." Hesperia 58 (1989a): 267-276.

Hoff, M. C. "The early history of the Roman Agora at Athens." In The Greek Renaissance in the Roman Empire: Papers from the Tenth British Museum Classical Colloquium, edited by S. Walker and A. Cameron, 1-8. London: University of London, Institute of Classical Studies, 1989b.

Hoff, M. C. “Augustus, Apollo and Athens.” Museum Helveticum 49.2 (1992): 223-232.

Hoff, M. C. "The politics and architecture of the Athenian imperial cult." In Subject and Ruler: the Cult of the Ruling Power in Classical Antiquity. Papers Presented at a Conference held in The 
University of Alberta on April 13-15, 1994, to Celebrate the 65th Anniversary of Duncan Fishwick, edited by A. Small, 185-200. Ann Arbor: Journal of Roman Archaeology, 1996.

Hoff, M. C. "Athens honors Pompey the Great.” In The Statesman in Plutarch's Works. Proceedings of the Sixth International Conference of the International Plutarch Society, Nijmegen/ Castle Hernen, May 1-5, 2002. Volume II: the Statesman in Plutarch's Greek and Roman Lives, edited by L. de Blois, 327-336. Leiden: Brill, 2005.

Hoff, M. C. "Greece and the Roman Republic: Athens and Corinth from the late third century to the Augustan era." In A Companion to the Archaeology of the Roman Republic, edited by J. DeRose Evans, 559-578. Oxford: Wiley-Blackwell, 2013.

Hölscher, T. The Languages of Images in Roman Art. Translated by A. Snodgrass and A. KünzlSnodgrass. Cambridge: Cambridge U. P., 2004.

Hurwit, J. M. The Athenian Acropolis: History, Mythology, and Archaeology from the Neolithic Era to the Present. Cambridge: Cambridge U. P., 1999.

Isaac, B. H. The Invention of Racism in Classical Antiquity. Princeton: Princeton U. P., 2004.

Johansen, F. S. "The portraits in marble of Gaius Julius Caesar: a review." In Ancient Portraits in the J. Paul Getty Museum. Volume 1, 17-40. Malibu: J. Paul Getty Museum, 1987.

Kajava, M. "Roman senatorial women and the Greek East: epigraphic evidence from the Republican and Augustan period." In Roman Eastern Policy and Other Studies in Roman History. Proceedings of a Colloquium at Tvärminne, 2-3 October 1987, edited by H. Solin and M. Kajava, 59-124. Helsinki: Societas Scientiarum Fennica, 1990.

Kajava, M. "Vesta and Athens." In The Greek East in the Roman Context: Proceedings of a Colloquium Organised by the Finnish Institute at Athens; May 21 and 22, 1999, edited by 0. Salomies, 71-94. Helsinki: Suomen Ateenan-instituutin säätiö, 2001.

Kaltsas, N. E. Sculpture in the National Archaeological Museum, Athens. Translated by D. Hardy. Los Angeles: J. Paul Getty Museum, 2002.

Kantiréa, M. Les dieux et les dieux Augustes. Le culte impérial en Grèce sous les Julio-claudiens et les Flaviens: études épigraphiques et archéologiques. Paris: De Boccard, 2007.

Keesling, C. "The Hellenistic and Roman afterlives of dedications on the Athenian Akropolis." In Die Akropolis von Athen im Hellenismus und in der römischen Kaiserzeit, edited by R. Krumeich and C. Witschel, 303-327. Wiesbaden: Reichert, 2010.

Kiss, Z. Etudes sur le portrait impérial Romain en Egypte. Warsaw: Editions scientifiques de Pologne, 1984.

Koortbojian, M. The Divinization of Caesar and Augustus: Precedents, Consequences, Implications. Cambridge: Cambridge U. P., 2013.

Kroll, J. H. The Greek Coins. Princeton: American School of Classical Studies at Athens, 1993.

Kuin, I. N. I. 'Anchoring political change in post-Sullan Athens.' In Strategies of Remembering in Greece under Rome (100 BC-100 AD), edited by T. M. Dijkstra, I. N. I. Kuin, M. Moser and D. Wiedgenannt, 157-167. Leiden: Sidestone, 2017.

Lang, M. L. and M. Crosby. Athenian Weights, Measures, and Tokens. Princeton: American School of Classical Studies at Athens, 1964.

Lange, C. H. Res publica constituta. Actium, Apollo, and the Accomplishment of the Triumviral Assignment. Leiden: Brill, 2009.

La Rocca, E. "Pompey Magno novus Neptunus." Bollettino della commissione archeologica comunale di Roma 92 (1987-1988): 265-292.

Lewis, D. M. "The chronology of the Athenian new style coinage." Numismatic Chronicle and Journal of the Royal Numismatic Society 7.2 (1962): 275-300. 
Mango, E. "Tanta vis admonitionis inest in locis. Zur Veränderung von Errineringsräumen im Athen des 1. Jahrhunderts v. Chr." In Die Akropolis von Athen im Hellenismus und in der römischen Kaiserzeit, edited by R. Krumeich and C. Witschel, 117-155. Wiesbaden: Reichert, 2010.

Mattingly, H. B. "Some third magistrates in the Athenian new style silver coinage." Journal of Hellenic Studies 91 (1971): 85-93.

Mattingly, H. B. “L. Julius Caesar, governor of Macedonia.” Chiron 9 (1979): 147-167.

Mayer, E. "Propaganda, staged applause, or local politics? Public monuments from Augustus to Septimius Severus." In The Emperor and Rome: Space, Representation, and Ritual, edited by B. Ewald and C. Noreña, 111-134. Cambridge: Cambridge U. P., 2010.

Mikalson, J. D. Religion in Hellenistic Athens. Berkeley: University of California, 1998.

Mitsopoulou, C. "The Eleusinia processional cult vessel: iconographic evidence and interpretation." In Current Approaches to Religion in Ancient Greece. Papers Presented at a Symposium at the Swedish Institute at Athens, 17-19 April 2008, edited by M. Haysom and J. Wallensten, 189-226. Stockholm: Svenska Institutet i Athen, 2011.

Morales, F. A., "The monument of Roma and Augustus on the Athenian Acropolis: imperial identities and local traditions." In Imperial Identities in the Roman World, edited by W. Vanacker and A. Zuiderhoek, 141-161. London: Routledge, 2017.

Mørkholm, 0. "The chronology of the new style coinage of Athens." Museum Notes. The American Numismatic Society 29 (1984): 29-42.

Moser, M. “Reused statues for Roman friends: the past as a political resource in Roman Athens.' In Strategies of Remembering in Greece under Rome (100 BC-100 AD), edited by

T. M. Dijkstra, I. N. I. Kuin, M. Moser and D. Wiedgenannt, 169-181. Leiden: Sidestone, 2017.

Newby, Z. "Performing the past: Salamis, naval contests and the Athenian ephebeia." In Strategies of Remembering in Greece under Rome (100 BC - 100 AD), edited by T. M. Dijkstra, I. N. I. Kuin, M. Moser and D. Wiedgenannt, 83-95. Leiden: Sidestone, 2017.

Nock, A. "Soter and euergetes." In The Joy of Study: Papers on New Testament and Related Subjects Presented to Honor Frederick Clifton Grant, edited by S. E. Johnson, 127-148. New York: Macmillan, 1951.

Noreña, C. F. Imperial Ideals in the Roman West: Representation, Circulation, Power. Cambridge: Cambridge U. P., 2011.

Orlin, E. M. "Octavian and Egyptian cults: redrawing the boundaries of Romanness." American Journal of Philology 129.2 (2008): 231-253.

Parigi, C. "The Romanization of Athens: Greek identity and connectivity between Athens and Rome in the 1st century BC." In SOMA 2012. Identity and Connectivity: Proceedings of the 16th Symposium on Mediterranean Archaeology, Florence, Italy, 1-3 March 2012. Volume I, edited by L. Bombardieri, 447-455. Oxford: Archaeopress, 2013.

Payne, M. J. Aretas Eneken: Honors to Romans and Italians in Greece from 260 to 27 BC. Dissertation. Michigan State University, 1984.

Pitts, M. and M. J. Versluys, editors. Globalisation and the Roman World: World History, Connectivity and Material Culture. Cambridge: Cambridge U. P., 2015.

Price, S. R. F. Rituals and Power: the Roman Imperial Cult in Asia Minor. Cambridge: Cambridge U. P., 1984.

Raja, R. Urban Development and Regional Identity in the Eastern Roman Provinces, 50 BC-AD 250: Aphrodisias, Ephesos, Athens, Gerasa. Copenhagen: Museum Tusculanum, 2012.

Rathmann, M. "Athen in hellenistischer Zeit-Fremdbestimmung und kulturelle Anziehungskraft." In Die Akropolis von Athen im Hellenismus und in der römischen Kaiserzeit, edited by R. Krumeich and C. Witschel, 55-93. Wiesbaden: Reichert, 2010. 
Raubitschek, A. E. “Octavia's deification at Athens." Transactions and Proceedings of the American Philological Association 77 (1946): 146-150.

Raubitschek, A. E. “Notes on Julius Caesar.” Journal of Roman Studies 44 (1954): 65-75.

Raubitschek, A. E. "Brutus in Athens." Phoenix 11.1 (1957): 1-11.

Raubitschek, A. E. "The Brutus statue in Athens." In Atti del terzo congresso internazionale di epigrafia greca e latina (Roma, 4-8 Settembre 1957), 15-21. Rome: L’Erma di Bretschneider, 1959 ,

Rawson, E. D. “Cicero and the Areopagus.” Athenaeum 63 (1985): 44-67.

Rödel-Braune, C. "Von Lucius Aemilius Paullus zu Augustus. Stiftungen von Römern in Athen.” In Die Akropolis von Athen im Hellenismus und in der römischen Kaiserzeit, edited by R. Krumeich and C. Witschel, 95-115. Wiesbaden: Reichert, 2010.

Rose, C. B. “The Parthians in Augustan Rome.” American Journal of Archaeology 109.1 (2005): 21-75.

Rosillo-López, C. "Greek self-representation to the Roman Republican power." In Ruling the Greek World: Approaches to the Roman Empire in the East, edited by F. Lozano, E. Muñiz Grijalvo and J. M. Cortés Copete, 13-26. Stuttgart: Steiner, 2015.

Rostovtzeff, M. “Augustus und Athen.” In Festschrift zu Otto Hirschfelds sechzigsten Geburtstage, 303-311. Berlin: Weidmannsche Buchhandlung, 1903.

Schmalz, G. C. R. Public Building and Civic Identity in Augustan and Julio-Claudian Athens. Dissertation. University of Michigan, 1994.

Schmalz, G. C. R. "Athens, Augustus, and the settlement of 21 B.C.” Greek, Roman and Byzantine Studies 37.4 (1997): 381-398.

Schmalz, G. C. R. "Inscribing a ritualized past: the attic restoration decree IG II2 1035 and cultural memory in Augustan Athens." Eulimene 8/9 (2008): 9-46.

Schmitz, T. A. and N. Wiater, editors. The Struggle for Identity. Greeks and Their Past in the first century BCE. Stuttgart: Steiner, 2011.

Schramm, W. "How communication works." In The Process and Effects of Mass Communication, edited by W. Schramm, 3-26. Urbana: University of Illinois, 1954.

Shear, J. L. "Reusing statues, rewriting inscriptions and bestowing honours in Roman Athens." In Art and Inscriptions in the Ancient World, edited by Z. Newby and R. E. Leader-Newby, 221-246. Cambridge: Cambridge U. P., 2007.

Shear Jr., T. L. “Athens: from city state to provincial town.” Hesperia 40.4 (1981): 356-377.

Spawforth, A. J. S. "Symbol of unity? The Persian wars tradition in the Roman Empire." In Greek Historiography, edited by S. Hornblower, 233-247. Oxford: Clarendon, 1997.

Spawforth, A. J. S. Greece and the Augustan Cultural Revolution. Cambridge: Cambridge U. P., 2012.

Sluiter, I. "Anchoring innovation: a Classical research agenda." European Review 25.1 (2017): 20-38.

Stanwick, P. E. Portraits of the Ptolemies: Greek kings as Egyptian pharaohs. Austin: University of Texas, 2002.

Stewart, D. "Review of A. J. S. Spawforth, Greece and the Augustan Cultural Revolution." Bryn Mawr Classical Review 2012.12.04. 2012.

Stefanidou-Tiveriou, T. "Tradition and romanization in the monumental landscape of Athens."

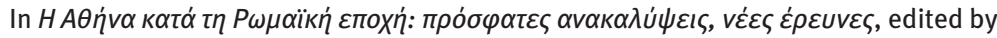
S. Vlizos, 11-39. Athens: Benaki Museum, 2008.

Strootman, R. Courts and Elites in the Hellenistic Empires: the Near East After the Achaemenids, c. 330 to 30 BCE. Edinburgh: Edinburgh U. P., 2014 a. 
Strootman, R. "The dawning of a golden age: images of peace and abundance in Alexandrian court poetry in the context of Ptolemaic imperial ideology." In Hellenistic Poetry in Context. Tenth International Workshop on Hellenistic Poetry, Groningen 25th-27th August 2010, edited by G. C. Wakker, R. F. Regtuit and A. Harder, 325-341. Leuven: Peeters, 2014b.

Strootman, R. "Antiochos IV and Rome: the festival at Daphne (Syria), the treaty of Apameia and the revival of Seleukid expansionism in the West." In Rome and the Seleukid East: Select Papers from Seleukid Study Day V, Université Libre de Bruxelles, 21-23 Aug. 2015, edited by A. Coşkun and D. Engels. Brussels: Éditions Latomus, forthcoming.

Swain, H. and M.E. Davies. Aspects of Roman History 82 BC-AD 14: a Source Based Approach. New York: Routledge, 2010.

Telin, A. "Roman visitors in Athens (II-I c. BC)." In Im Schatten der Alten? Ideal und Lebenswirklichkeit im römischen Griechenland. 3. Heidelberger Altertumswissenschaftliches Studierendenkolloquium 8.-10. November 2013, edited by J. Fouquet and L. Gaitanou, 187-193. Wiesbaden: Harrassowitz, 2016.

Thakur, S. "Identity under construction in Roman Athens." In Negotiating the Past in the Past: Identity, Memory, and Landscape in Archaeological Research, edited by N. Yoffee, 104-127. Tucson: University of Arizona, 2007.

Thompson, H. A. "The impact of Roman architects and architecture on Athens: 170 B.C.-A.D. 170." In Roman Architecture in the Greek World, edited by S. Macready and F. H. Thompson, 1-17. London: Society of Antiquaries of London, 1987.

Thompson, M. The New Style Silver Coinage of Athens. New York: American Numismatic Society, 1961.

Toynbee, J. M. C. "Portraits of Julius Caesar." Greece and Rome 4.1 (1957): 2-9.

Tversky A. and D. Kahneman. "Judgement under uncertainty: heuristics and biases." Science (New Series) 185.4157 (1974): 1124-1131.

Vanderpool, E. “Three inscriptions from Eleusis.” Apхаııһoүıкóv $\Delta \varepsilon \lambda$ tiov 23.1 (1968): 1-9.

Versnel, H. S. Triumphus: an Inquiry into the Origin, Development and Meaning of the Roman Triumph. Leiden: Brill, 1970.

Vlassopoulos, K. "Review of A. J. S. Spawforth, Greece and the Augustan Cultural Revolution." Classical Review 63.1 (2013): 182-184.

Walker, S. "Athens under Augustus." In The Romanization of Athens. Proceedings of an International Conference Held at Lincoln, Nebraska (April 1996), edited by M. C. Hoff and S. I. Rotroff, 67-80. Oxford: Oxbow, 1997.

Wallace-Hadrill, A. Rome's Cultural Revolution. Cambridge: Cambridge U. P., 2008.

Waterfield, R. Taken at the Flood: the Roman Conquest of Greece. Oxford: Oxford U. P., 2014.

Weinstock, S. Divus Julius. Oxford: Clarendon, 1971.

Whittaker, H. "Some reflections on the Temple to the goddess Roma and Augustus on the Acropolis at Athens." In Greek Romans and Roman Greeks: Studies in Cultural Interaction, edited by E. N. Ostenfeld, 25-39. Aarhus: Aarhus U. P., 2002.

Zanker, P. Provinzielle Kaiserporträts: zur Rezeption der Selbdarstellung des Princeps. Munich: Verlag der Bayerischen Akademie der Wissenschaften, 1983.

Zanker, P. The Power of Images in the Age of Augustus. Translated by A. Shapiro. Ann Arbor: University of Michigan, 1988.

Zanker, P. "The irritating statues and contradictory portraits of Julius Caesar." In A Companion to Julius Caesar, edited M. T. Griffin, 288-314. Chichester: Wiley-Blackwell, 2009. 